V. M. Korendiy, O. Yu. Kachur, Yu. Ya. Novitskyi, V. A. Mazuryk, V. A. Sereda Lviv Polytechnic National University

\title{
SUBSTANTIATION OF PARAMETERS AND MODELLING THE OPERATION OF THREE-MASS VIBRATORY CONVEYER WITH DIRECTED OSCILLATIONS OF THE WORKING ELEMENT
}

\author{
(C) Korendiy V. M., Kachur O. Yu., Novitskyi Yu. Ya., Mazuryk V. A., Sereda V. A., 2019
}

https://doi.org/10.23939/istcipa2019.53.084

The purpose of research. The main goal of the presented research consists in substantiation of inertial, stiffness and force (excitation) parameters of mechanical oscillatory system of three-mass vibratory conveyer with directed oscillations of the working element in order to provide the highly efficient (high-performance) resonant operation mode. Methodology. The technique of the research is based on fundamental concepts of engineering mechanics and theory of mechanical vibrations. In order to deduce the differential equations of motion of the mechanical oscillatory system of vibratory conveyer the Lagrange equations of the second order were used. The computation modelling of the system's motion caused by periodic excitation forces was carried out using MathCAD software with a help of Runge-Kutta method. Results. The existent structures of vibratory conveyers, as well as the fields and peculiarities of their implementation, are considered. The design of the three-mass vibratory conveyer with electromagnetic drive, directed oscillations of the working element, and resonant operation mode is proposed. The structural diagram of the conveyer's mechanical oscillatory system is developed and its dynamics is investigated. Scientific novelty. The mathematical model of motion of the mechanical oscillatory system of the proposed conveyer is formed. The numerical modelling of motion of the oscillating masses of the vibratory conveyer was carried out for different operation modes. The influence of the excitation parameters (the frequency and amplitude of the excitation force) on the characteristics of oscillations of the conveyer's working element was investigated. Practical value. The results of the carried out investigations can be used while designing and developing various vibratory equipment for conveying, separating and treating of different loose, bulky and piece-wise products.

Keywords: vibratory conveyer, mechanical oscillatory system, vibration exciter, resonant operation mode, inertial parameters, stiffness parameters, excitation parameters, frequency, amplitude.

Introduction. Nowadays, the world's leading corporations manufacture electromagnetic-driven vibratory machines, usually based on the two-mass scheme. There is almost no serial (commercial) industrial production of large-scale vibratory equipment with three-mass mechanical oscillatory systems not only with electromagnetic, but also with unbalanced vibration exciters. From time to time, such schemes find application only in relatively small and low-power structures of vibratory conveyors, hoppers, feeders, dispensers, weighers, separators, mixers, batchers etc.

The problems of investigating motion dynamics and substantiating technical and operational parameters of vibratory conveyers considered as mechanical oscillatory systems able to operate in different (pre-resonant, near-resonant, after-resonant) modes and with different loadings of the working element are currently urgent. In particular, in the present paper, there will be substantiated the possibilities of practical implementation, as well as structural and excitation parameters of the three-mass vibratory conveyer with directed oscillations of the working element.

Analysis of modern information sources on the subject of research. The subject of mechanical vibrations is widely considered all over the world [1-3]. One of the most interesting and useful topics related with mechanical vibrations that is lively discussed by scientists and designers consists in application of theoretical knowledge in the processes of calculating, designing, manufacturing and operating of various vibratory equipment [4-9]. Among all the fields of implementation of vibratory equipment, one of the most investigated is vibratory conveying one [5-7]. There are a wide range of vibratory conveyers being manufactured by hundreds of companies all over the world [4-7]. Nevertheless, the problems of substantiation of optimal inertial, stiffness and excitation parameters of vibratory conveyers are of the greatest interest among the scientists working on this subject [6-9]. Especially, there 
are no exact and widely used techniques of calculating the parameters of multi-mass (three-mass, fourmass etc.) vibratory systems able to convey different types of products (loose, bulky, piece-wise etc.). The investigations presented in this paper are based on the considerable research and experimental achievements of the school of vibration technologies of Lviv Polytechnic National University [5-9]. Some results of the investigations have been already considered at different conferences, in particular [9]. In the paper, there will be presented the whole material related with design development, parameters calculation, and operation modelling of the three-mass vibratory conveyer with directed oscillations of the working element.

The purpose of research. The purpose of this paper consists in developing the design of three-mass vibratory conveyer with directed oscillations of the working element; substantiating inertial and stiffness parameters of its mechanical oscillatory system in order to ensure the highly-efficient (high-performance) resonant operation mode; investigating the influence of loading value on the conveyer's dynamics.

Design and operation peculiarities of the vibratory conveyer. The general design of the vibratory conveyer is presented in Fig. 1. It consists of the active mass (working element, tray) 1, along which the loads of different structure (loose, bulky, piece-wise etc.) can be conveyed. The working element is placed on the intermediate mass (frame, body) 2 with a help of spring elements (sets of flat springs) 4 . The frame 2 is placed on the immovable base (foundation) using soft textolite spring elements (vibration isolators) 8 and supports 9. The reactive (exciting) mass 6 with the armatures of the disturbing electromagnets is attached to the intermediate mass 2 with a help of the textolite spring elements 5 . The coils 7 of the electromagnetic vibration exciters are fixed on the intermediate mass 2 and are powered by the electric network according to the two-cycle scheme.

The operation principle of the considered design of vibratory conveyer consists in following. When supplying the sinusoidal current to the coils of electromagnets 7, the periodical (alternating) excitation force arises between the armatures 6 and coils 7. The magnitude of this force is proportional to the magnitude of the supplied voltage, and the frequency of this force is equal to the frequency of the electric network. The reactive mass 6 oscillates due to the action of the disturbing (alternating) force and excites the oscillations of the intermediate mass 2 through the spring elements 5 . The vibratory motion of the working element 1 is caused by the intermediate mass 2 with a help of flat springs 4 . In order to provide the conveying of products along the tray 1 , it is necessary to make the working element oscillate along the straight line at certain vibration angle (throwing angle). In addition, depending on the conveying type (detached or non-detached), there should be provided a certain acceleration of the working element.

One of the greatest problems arising during the designing and calculating of vibratory conveyers with directed oscillations of the working elements consists in the necessity of providing the location of all mass centres of the whole oscillatory system on one straight line [5-7]. At the same time, in order to minimize the parasitic (spurious, undesired) oscillations, it is necessary to make the line of action of the excitation force of the electromagnetic drive coincide with the line that attach all mass centres of the mechanical oscillatory system [5-7]. As can be seen in Fig. 2, the stated principle has been taken into account while designing the investigated vibratory conveyer.

One more important task arising during designing and calculating of the vibratory conveyers consists in providing the constant (stable) frequency of oscillations along the whole working element (tray) [5-7]. When the previously mentioned condition (coincidence of the line of action of the excitation force with the line attaching the mass centres) is satisfied, it is necessary to ensure the satisfactory rigidity (stiffness) of the working element. This task stipulates the frequency analysis of the working element considered as a body with distributed mass and providing its first natural frequency (eigenfrequency) 2-4 times larger than the excitation (forced) frequency of the electromagnetic drive [5-7]. The computer solidstate modelling of the investigated vibratory conveyer in the applied software SolidWorks allowed to determine the first natural frequency (eigenfrequency) of the working element (tray) using the FiniteElement Method. The obtained result $v_{0}=104.12 \mathrm{~Hz}$ is almost twice larger than the forced frequency $v=50 \mathrm{~Hz}$. The additional increasing of the rigidity (stiffness) of the working element can be provided by increasing the width and the number of ribs, but this considerably enlarges the mass of the conveyer. 


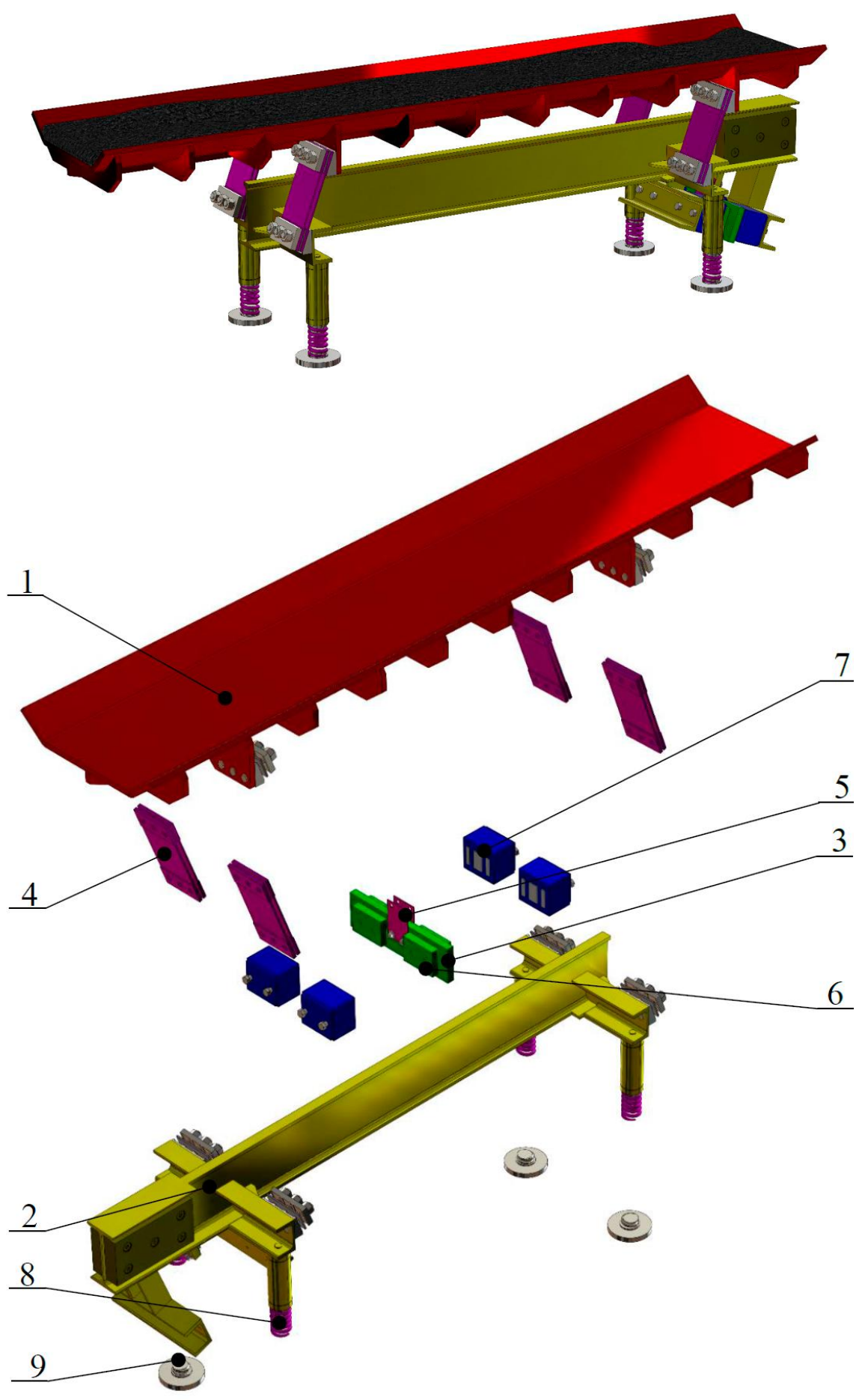

Fig. 1. Design diagram of the three-mass vibratory conveyer with directed oscillations of the working element

Рис. 1. Загальний вигляд тримасового вібротранспортера з напрямленими коливаннями робочого органу

Calculation diagram of the mechanical oscillatory system of the vibratory conveyer. In this part of the paper, there will be initiated the prerequisites for further deducing the mathematical model of the conveyer's mechanical oscillatory system and simulating its motion. In particular, there will be substantiated the calculation diagram of the oscillatory system and its inertial and stiffness parameters, which will be used while deriving the differential equations of the system's motion. 


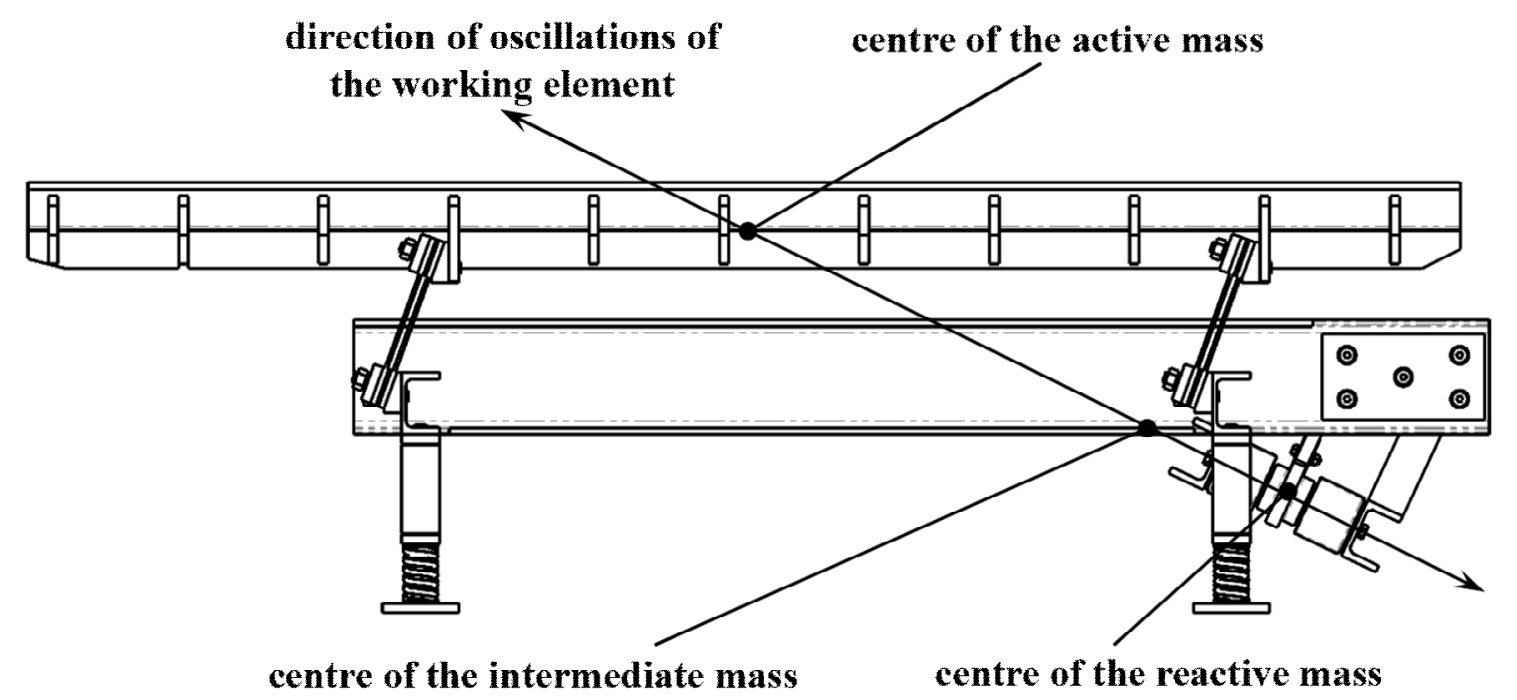

Fig. 2. Principal diagram of the vibratory conveyer design ensuring minimization of parasitic oscillations

Рис. 2. Принципова схема компонування вібротранспортера з метою мінімізачії паразитних коливань

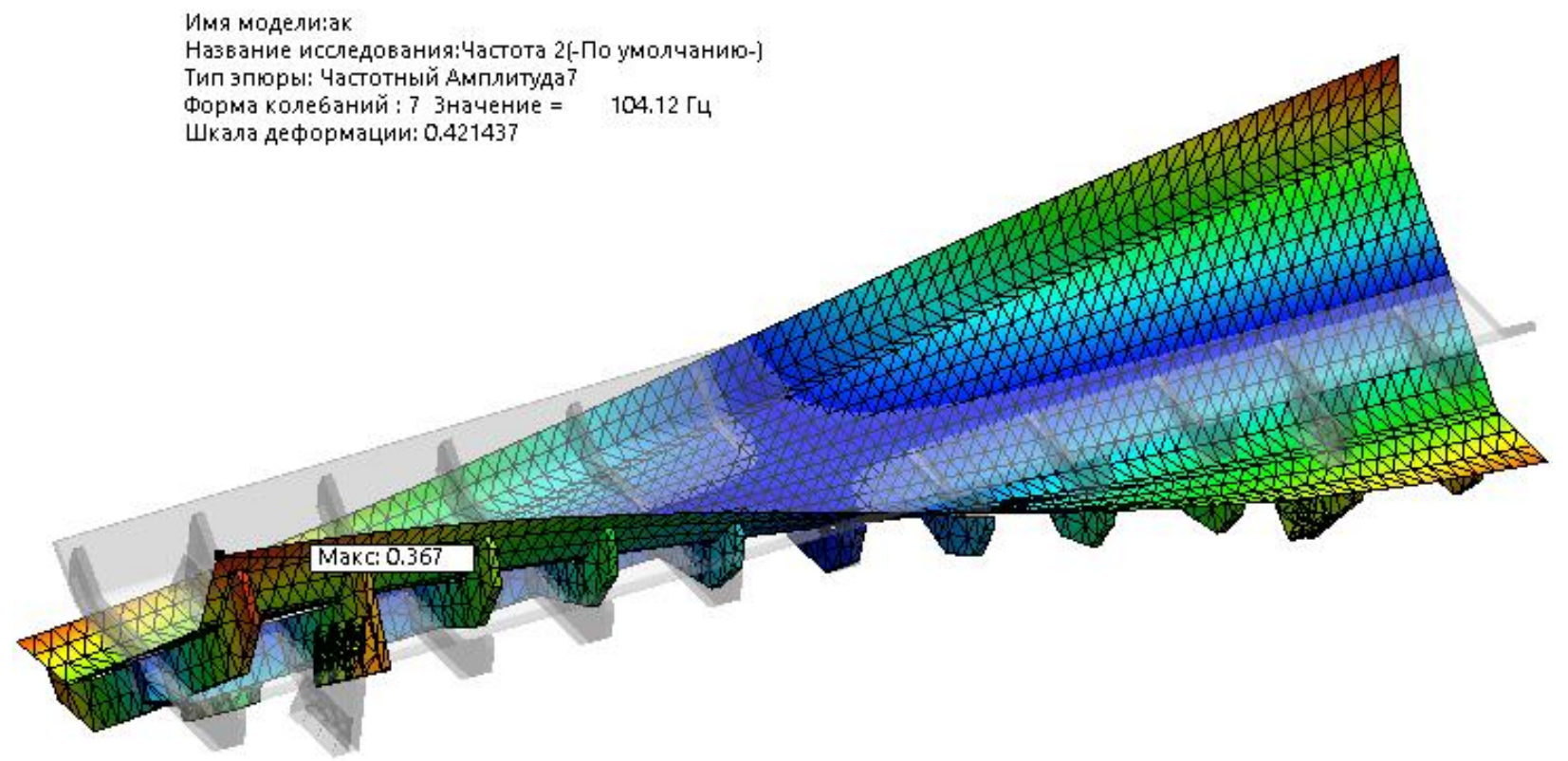

Fig. 3. Results of computer analysis of the natural frequencies of the vibratory conveyer's working element in SolidWorks software

Рис. 3. Результати комп'ютерного розрахунку власних частот робочого органу вібротранспортера у програмному продукті SolidWorks

On the basis of the design diagrams of the vibratory conveyer (Figs. 1 and 2), let us construct its plane calculation (kinematic) diagram (Fig. 4). Let us adopt the following notations: $m_{a}-$ active mass (the mass of the working element 1 ); $m_{n}$ - intermediate mass (the mass of the vibratory conveyer's frame 2); $m_{p}$ - reactive mass (the mass of the disturbing body 3 ); $c_{1}, \mu_{1}, c_{2}, \mu_{2}, c_{i 3}, \mu_{i 3}$ - coefficients of stiffness and damping of the spring elements 4, 5, 6, respectively; $p(t)$ - periodically alternating (sinusoidal) excitation force applied between the bodies 1 and 3, and directed along the line attaching the 
mass centres of all bodies of the mechanical oscillatory system; $x_{1}, x_{2}, x_{3}$-generalized coordinates that definitely determine the position of each oscillating mass (active 1 , intermediate 2 , reactive 3 , respectively) during their motion along the line of action of the excitation force.

The working bodies of the system (disturbing mass $m_{p}$, frame $m_{n}$, tray $m_{a}$ ) can move along the line attaching their mass centres and coinciding with the line of action of the excitation force. These masses are considered as perfectly rigid bodies. In order to describe the motion of each mass, there are used the corresponding generalized coordinates $x_{1}, x_{2}, x_{3}$. While developing the mathematical model of the mechanical oscillatory system and while carrying out further investigations, let us neglect the geometrical sizes and shapes of the working bodies, and let us consider them as particles (mass points). Also let us adopt that the bodies are attached by the elastic-tough elements with coefficients of stiffness $c_{1}$, $c_{2}, c_{i 3}$, and coefficients of damping (viscous friction) $\mu_{1}, \mu_{2}, \mu_{i 3}$. While describing the potential forces, let us consider that the deformations of the spring elements perform according to the Hook's law.

In order to describe the excitation force, let us adopt the harmonic (sinusoidal) law, which describes the traction force of the electromagnetic vibration exciter with sufficient accuracy [5-7]. For practical implementation of the harmonic oscillations, it is necessary to power the coils of the electromagnets according to the two-cycle scheme. It provides the use of one half-cycle (half-period) of the current for powering the coil of one electromagnet, while the other half-cycle (half-period) is used for powering the coil of the second electromagnet [5-7].

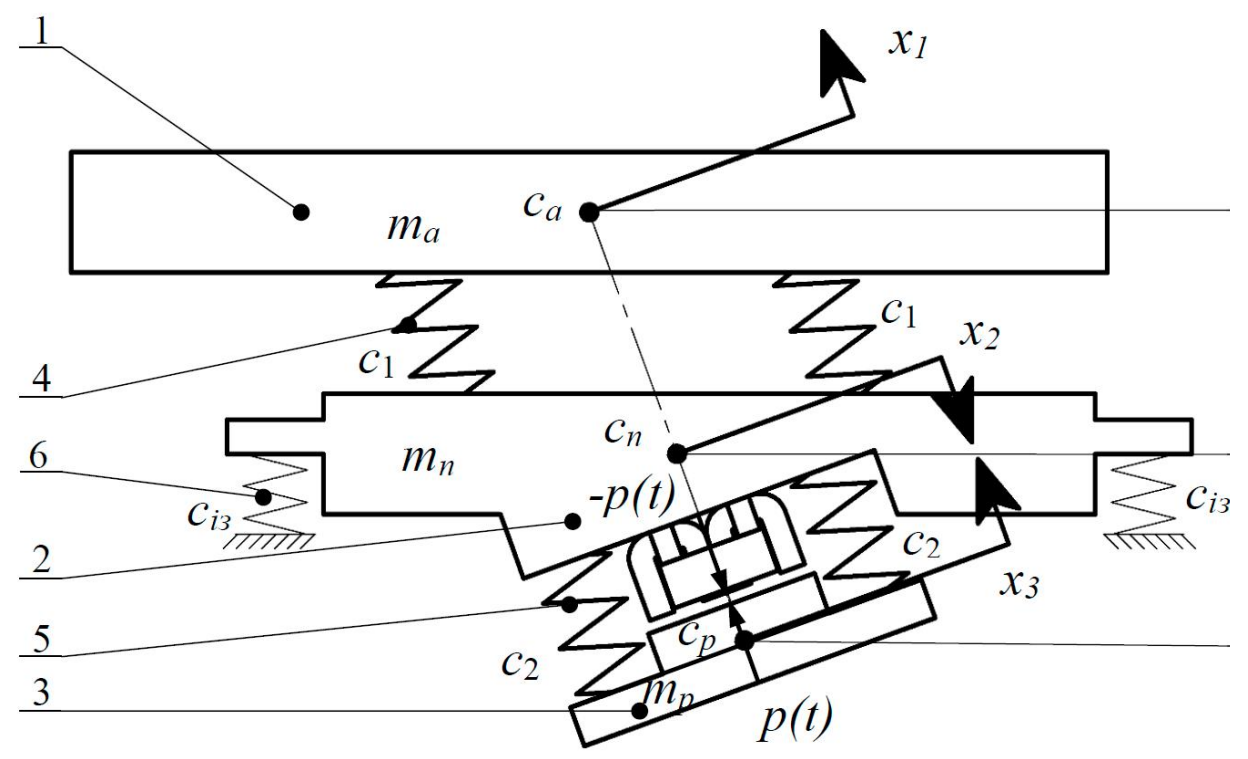

Fig. 4. Calculation diagram of the mechanical oscillatory system of the vibratory conveyer

Рис. 4. Розрахункова схема механічної коливальної системи вібротранспортера

The active mass 1 , intermediate mass 2 , and reactive mass 3 with corresponding inertial parameters $m_{a}, m_{n}, m_{p}$, perform the straight-line oscillations described by generalized coordinates $x_{1}, x_{2}, x_{3}$, respectively (Fig. 4). The active mass 1 (working element, tray) moves due to the kinematic disturbance caused by the intermediate mass 2 that is attached to the active mass 1 by the spring elements 4 . The excitation of the forced vibrations takes place due to two sinusoidal forces $p(t)=P \sin \omega t$ and $p(t)=-P \sin \omega t$ acting between the intermediate and reactive masses ( $P$ is the amplitude value of the excitation force; $\omega$ is the frequency of forced vibrations; $t$ is time). The active and the intermediate 
masses, as well as the intermediate and reactive masses are pairwise (mutually) attached by spring elements 4 and 5, respectively. The coefficients of stiffness of corresponding spring elements are $c_{1}$ and $c_{2}$. The mechanical oscillatory system of the vibratory conveyer is placed on the immovable base (foundation) with a help of the spring elements (vibration isolators) 6 with stiffness $c_{i 3}$. The vibration isolators are attached to the intermediate mass and to the supports placed on the foundation.

The selection of rational (optimal) inertial and stiffness parameters of the oscillatory system of the vibratory conveyer, as well as the parameters of excitation (frequency and amplitude of the excitation force), one can provide the optimal conveying of products (i.e. optimal parameters of motion of the working element, along which the products are conveyed). This problem requires the differential equations of motion of the mechanical oscillatory system of the vibratory conveyer with further substantiation of its optimal operation modes.

Forming the mathematical model of the mechanical oscillatory system of the vibratory conveyer. In order to derive the differential equations of motion of the mechanical oscillatory system of vibratory conveyer, let use the Lagrange equations of the second order. Let us consider the unstable straight-line motion of the mechanical oscillatory system along the line of action of the excitation force (Fig. 4). The generalized coordinates describe the displacements of the mass centres of the working element (active mass) $x_{1}$, frame (intermediate mass) $x_{2}$, and disturbing body (reactive mass) $x_{3}$. The Lagrange equations of the second order for the considered mechanical oscillatory system of the vibratory conveyer are of the following form:

$$
\left\{\begin{array}{l}
\frac{d}{d t}\left(\frac{\partial T}{\partial \dot{x}_{1}}\right)-\frac{\partial T}{\partial x_{1}}=-\frac{\partial \Pi}{\partial x_{1}}+Q_{x_{1}} \\
\frac{d}{d t}\left(\frac{\partial T}{\partial \dot{x}_{2}}\right)-\frac{\partial T}{\partial x_{2}}=-\frac{\partial \Pi}{\partial x_{2}}+Q_{x_{2}} \\
\frac{d}{d t}\left(\frac{\partial T}{\partial \dot{x}_{3}}\right)-\frac{\partial T}{\partial x_{3}}=-\frac{\partial \Pi}{\partial x_{3}}+Q_{x_{3}}
\end{array}\right.
$$

where $T, \Pi$ are kinetic and potential energies of the mechanical oscillatory system of the vibratory conveyer; $Q_{x i}$ are the generalized forces acting upon the bodies of the system and corresponding to the adopted generalized coordinates; $\dot{x}_{i}$ are the generalized speeds of the bodies of the system, which correspond to the generalized coordinates $x_{i}$.

Taking into account the fact that all the bodies of the system oscillate along a straight line with speeds $\dot{x}_{1}, \dot{x}_{2}, \dot{x}_{3}$, the total kinetic energy of the mechanical oscillatory system can be calculated by the following formula:

$$
T=\frac{m_{a} \dot{x}_{1}^{2}}{2}+\frac{m_{n} \dot{x}_{2}^{2}}{2}+\frac{m_{p} \dot{x}_{3}^{2}}{2} .
$$

Let us determine the potential energy $\Pi$ of the mechanical oscillatory system using the sum of mechanical works of the restoring forces of the spring elements:

$$
\Pi=\frac{1}{2} c_{1}\left(x_{1}-x_{2}\right)^{2}+\frac{1}{2} c_{2}\left(x_{2}-x_{3}\right)^{2}+\frac{1}{2} c_{i 3} x_{2}^{2} .
$$

While deriving the differential equations of motion of the oscillatory system of the vibratory conveyer, let us neglect the coefficients of viscous friction in spring elements. This assumption is proven by numerous investigations in the field of vibratory conveying, which state that viscous friction of the metal coil-type and flat springs does not significantly influence the displacement of the resonance peaks in 
the frequency field of the oscillatory system [5-7]. This displacement is in the range of 3\% [5-7]. That is why we assume $\mu_{1}=0, \mu_{2}=0, \mu_{i 3}=0$ in further calculations and computer simulation.

The excitation force $p(t)$ is modelled as the periodical function changing according to the sinusoidal law. In this case, the intermediate and the reactive masses are acted upon by the forces:

$$
\begin{gathered}
Q_{x_{2}}=-P \cdot \sin (\omega \cdot t) ; \\
Q_{x_{3}}=P \cdot \sin (\omega \cdot t),
\end{gathered}
$$

where $P, \omega$ are the amplitude and the frequency of the excitation force, respectively; $t$ is time.

Let us determine the corresponding partial derivatives of the expressions (2) of the system's kinetic energy and of the expressions (3) of the system's potential energy:

$$
\begin{gathered}
\frac{\partial T}{\partial \dot{x}_{1}}=m_{a} \dot{x}_{1} ; \quad \frac{d}{d t}\left(\frac{\partial T}{\partial \dot{x}_{1}}\right)=m_{a} \ddot{x}_{1} ; \quad \frac{\partial T}{\partial x_{1}}=0 ; \quad \frac{\partial \Pi}{\partial x_{1}}=c_{1}\left(x_{1}-x_{2}\right) ; \quad \frac{\partial T}{\partial \dot{x}_{2}}=m_{n} \dot{x}_{2} ; \\
\frac{d}{d t}\left(\frac{\partial T}{\partial \dot{x}_{2}}\right)=m_{n} \ddot{x}_{2} ; \quad \frac{\partial T}{\partial x_{2}}=0 ; \quad \frac{\partial \Pi}{\partial x_{2}}=c_{1}\left(x_{2}-x_{1}\right)+c_{2}\left(x_{2}-x_{3}\right)+c_{i_{3}} x_{2} ; \\
\frac{\partial T}{\partial \dot{x}_{3}}=m_{p} \dot{x}_{3} ; \quad \frac{d}{d t}\left(\frac{\partial T}{\partial \dot{x}_{3}}\right)=m_{p} \ddot{x}_{3} ; \quad \frac{\partial T}{\partial x_{3}}=0 ; \quad \frac{\partial \Pi}{\partial x_{3}}=c_{2}\left(x_{3}-x_{2}\right) .
\end{gathered}
$$

Taking into account the dependencies (4), (5) for determining the generalized forces and the expressions (6) for corresponding derivatives of kinematic and potential energies, let us write the differential equations (1) of motion of the mechanical oscillatory system of the vibratory conveyer in the following form:

$$
\left\{\begin{array}{l}
m_{a} \ddot{x}_{1}+c_{1}\left(x_{1}-x_{2}\right)=0 \\
m_{n} \ddot{x}_{2}+c_{1}\left(x_{2}-x_{1}\right)+c_{2}\left(x_{2}-x_{3}\right)+c_{i 3} x_{2}=-P \cdot \sin (\omega \cdot t) \\
m_{p} \ddot{x}_{3}+c_{2}\left(x_{3}-x_{2}\right)=P \cdot \sin (\omega \cdot t) .
\end{array}\right.
$$

In accordance with the general rules (methods) of solving the systems of linear nonhomogeneous differential equations with constant coefficients, the analytical expressions for describing the motion of the oscillating masses along three independent degrees of freedom can be presented in the following form [6, 7]: $x_{1}=X_{1} \cdot e^{i \cdot \omega \cdot t}, x_{2}=X_{2} \cdot e^{i \cdot \omega \cdot t}, x_{3}=X_{3} \cdot e^{i \cdot \omega \cdot t}$, where $X_{1}, X_{2}, X_{3}$ are the amplitude values of the linear displacements of the oscillating masses taking place during the system's forced vibrations, which correspond to the generalized coordinates $x_{1}, x_{2}, x_{3}$. Substituting these expressions into (7) and simplifying the obtained equations, one can obtain the dependencies for determining the amplitudes $X_{1}$, $X_{2}, X_{3}$. The process of solving the system (7) can be written in the following matrix form:

$$
\mathbf{X}=\mathbf{C}^{-1} \cdot \mathbf{P}
$$

where $\mathbf{X}$ is the column matrix of the unknowns; $\mathbf{C}^{-1}$ is the matrix of coefficients of the unknowns (stiffness matrix); $\mathbf{P}$ is the column matrix of the excitation forces. 
Let us write the equation (8) for the considered oscillatory system of the vibratory conveyer:

$$
\left[\begin{array}{ccc}
\left(c_{1}-m_{a} \omega^{2}\right) & -c_{1} & 0 \\
-c_{1} & \left(c_{1}+c_{2}+c_{i 3}-m_{n} \omega^{2}\right) & -c_{2} \\
0 & -c_{2} & \left(c_{2}-m_{p} \omega^{2}\right)
\end{array}\right]^{-1} \times\left[\begin{array}{c}
0 \\
-P \\
P
\end{array}\right]=\left[\begin{array}{c}
X_{1} \\
X_{2} \\
X_{3}
\end{array}\right] .
$$

Let us adopt the following notations:

$$
\begin{gathered}
k_{11}=c_{1}-m_{a} \omega^{2} ; \quad k_{12}=k_{21}=-c_{1} ; \\
k_{13}=0 ; \quad k_{22}=c_{1}+c_{2}+c_{i 3}-m_{n} \omega^{2} ; \\
k_{23}=k_{32}=-c_{2} ; \quad k_{31}=0 ; \quad k_{33}=c_{2}-m_{p} \omega^{2} .
\end{gathered}
$$

Let us present the solution of the matrix equation (9) in the form of expressions for determining the amplitudes of oscillations of the active mass $X_{1}$, intermediate mass $X_{2}$, and reactive mass $X_{3}$ in the steady-state operation mode:

$$
\begin{aligned}
& X_{1}=\frac{-P \cdot k_{12}\left(k_{23}+k_{33}\right)}{k_{12} k_{21} k_{33}-k_{11} k_{22} k_{33}+k_{11} k_{23} k_{32}} ; \\
& X_{2}=\frac{P \cdot k_{11}\left(k_{23}+k_{33}\right)}{k_{12} k_{21} k_{33}-k_{11} k_{22} k_{33}+k_{11} k_{23} k_{32}} ; \\
& X_{3}=\frac{-P \cdot\left(k_{11} k_{32}-k_{12} k_{21}+k_{22} k_{11}\right)}{k_{12} k_{21} k_{33}-k_{11} k_{22} k_{33}+k_{11} k_{23} k_{32}}
\end{aligned}
$$

Defining inertial and stiffness parameters of the conveyer's oscillatory system. On the basis of the results of solid-state modelling of the investigated vibratory conveyer in the SolidWorks software, let us define the input data for further calculations: the mass of the loaded working element (tray) $m_{a}=56.742 \mathrm{~kg}$; the mass of the conveyer's frame (intermediate mass) $m_{n}=36.055 \mathrm{~kg}$.

In order to provide the highly efficient (high-performance) resonant operation mode of the vibratory conveyer, it is necessary to ensure the in-phase motion of the reactive and intermediate masses with the simultaneous implementation of the effect of "zero-stiffness" [6, 7]. In this case, for determining the value of the reactive mass, the following formula can be used [6]:

$$
m_{p}=\frac{m_{n} \cdot\left(1-z^{2}\right) \cdot\left(m_{a}+m_{n}\right)}{z^{2} \cdot\left(m_{a}+m_{n}\right)-m_{n}}=\frac{36.055 \cdot\left(1-0.97^{2}\right) \cdot(56.742+36.055)}{0.97^{2} \cdot(56.742+36.055)-36.055}=3.858 \mathrm{~kg},
$$

where $z$ is the coefficient of resonance correction (the ration between the forced and natural frequencies of the oscillatory system). According to the recommendations [5-7], it was adopted $z=0.97$.

Therefore, on the basis of the defined value of the reactive mass $m_{p}=3.858 \mathrm{~kg}$, the corresponding thickness of the additional plates attached to the armatures of the electromagnets was determined. The plates were implemented in the design model of the vibratory conveyer.

In order to determine the necessary stiffness of the spring element between the active and the intermediate masses (i.e. between the tray and the frame), let us define the corresponding reduced mass $m_{36}$ in accordance with the recommendations given in [5]:

$$
m_{36}=\frac{m_{a} \cdot m_{n}}{m_{a}+m_{n}}=\frac{56.742 \cdot 36.055}{56.742+36.055}=22.048 \mathrm{~kg} .
$$


Taking into account the total number of spring elements $n=8$, let us recalculate the reduced mass per one spring element $m_{361}=\frac{m_{36}}{n}=\frac{22.048}{8}=2.756 \mathrm{~kg}$.

Using the defined value of the reduced mass, let us determine the minimal necessary stiffness $c_{1}$ of the spring unit (set):

$$
c_{1}=m_{36} \cdot\left(\frac{\omega}{z}\right)^{2}=22.048 \cdot\left(\frac{2 \cdot \pi \cdot 50}{0.97}\right)^{2}=2.313 \cdot 10^{6} \mathrm{~N} / \mathrm{m}
$$

and the minimal necessary stiffness $c_{11}$ of the single spring:

$$
c_{11}=m_{361} \cdot\left(\frac{\omega}{z}\right)^{2}=\frac{c_{1}}{n}=\frac{2.313 \cdot 10^{6}}{8}=2.891 \cdot 10^{5} \mathrm{~N} / \mathrm{m} .
$$

The minimal length of the working zone of the spring element equals $[5,6]$ :

$$
l_{c}=3 \cdot \delta_{x} \cdot k_{\text {кон }} \cdot \sqrt[3]{\frac{c_{1} \cdot E^{2}}{h \cdot n \cdot k \cdot[\sigma]^{3}}}=3 \cdot 0.00164 \cdot 1 \cdot \sqrt[3]{\frac{2.313 \cdot 10^{6} \cdot\left(2.1 \cdot 10^{11}\right)^{2}}{0.08 \cdot 8 \cdot 0.8 \cdot\left(330 \cdot 10^{6}\right)^{3}}}=0.077 \mathrm{~m},
$$

where $\delta_{x}$ is the maximal related displacement of the ends of the spring elements, which can be determined as $\delta_{x}=X_{1}+X_{2}==1.64 \mathrm{~mm}$ taking into account the expressions (11) (in the presented below results of modelling (simulation), there will be determined the values $X_{1}=0.6 \mathrm{~mm}, X_{2}=1.04 \mathrm{~mm}$ ); $k_{\kappa о н}=1$ is the coefficient taking into account the concentration of stresses; $[\sigma]$ is the tolerable (admissible) normal stress for the material of the spring (for spring steel $[\sigma]=330 \cdot 10^{6} \mathrm{~Pa}$ ); $E=2.1 \cdot 10^{11} \mathrm{~Pa}$ is the shearing (rigidity) modulus; $n=8$ is the number of the working zones of the spring system and equals to the number of springs used in the set (unit); $k=0.8$ is the coefficient of fixity (constraint) of the spring element $[5,6]$.

The necessary thickness of the spring element can be determined by the following formula $[5,6]$ :

$$
b=\sqrt[3]{\frac{c_{1} \cdot l_{c}^{3}}{E \cdot h \cdot n \cdot k}}=\sqrt[3]{\frac{2.313 \cdot 10^{6} \cdot 0.07714^{3}}{2.1 \cdot 10^{11} \cdot 0.08 \cdot 8 \cdot 0.8}}=0.00215 \mathrm{~m}
$$

In the proposed design of the vibratory conveyer (Figs. 1, 2), there are used four coil cylindrical springs as vibration isolators. With their help, the frame of the vibratory conveyer is placed on the supporting surface (base, foundation). The total mass of all the parts of the conveyer, which are supported by vibration isolators, is equal to $M=120.77 \mathrm{~kg}$. Taking into account the fact that the natural frequency of the single-mass oscillatory system supported by vibration isolators with stiffness $c_{i 3}$ should be much smaller than the forced frequency in order to minimize the influence of dynamic loads on the foundation (base), let us adopt the value of resonance correction equal to $z=5$.

Let us determine the minimal necessary natural frequency of the conveyer's vibration isolators [6]:

$$
\Omega_{\text {B iз }}=\frac{\omega}{z}=\frac{314.16}{5}=62.8 \frac{\mathrm{rad}}{\mathrm{s}} \quad\left(v_{\text {B } i 3}=10 \mathrm{~Hz}\right),
$$

where $\omega=314.16 \frac{\mathrm{rad}}{\mathrm{s}}$ is circular frequency of forced vibrations, which corresponds to the frequency of $50 \mathrm{~Hz}$ of the electric network.

In order to determine the necessary stiffness of one coil cylindrical spring of the vibration isolator, let us adopt the diameter of the spring wire $d_{\partial}=6 \mathrm{~mm}$, the middle diameter of the coil $D=30 \mathrm{~mm}$ and the number of coils $i_{6}=6$. In this case, the stiffness of the vibration isolators' springs is following [5, 6]:

$$
c_{i 3}=\frac{G \cdot d_{\partial}}{8 \cdot D^{3} \cdot i_{B}}=\frac{7.7 \cdot 10^{10} \cdot 0.006^{4}}{8 \cdot 0.03^{3} \cdot 6}=77000 \frac{\mathrm{N}}{\mathrm{m}} \text {. }
$$


Using the obtained value of stiffness of one vibration isolator, let us determine the natural frequency of the single-mass oscillatory system and compare it with the results obtained in (18):

$$
\Omega_{\text {в із розр. }}=\sqrt{\frac{c_{i_{3} \cdot i_{b}}}{M}}=\sqrt{\frac{77000 \cdot 6}{120.77}}=61.85 \frac{\mathrm{rad}}{\mathrm{s}} \approx \Omega_{\text {в із }}=62.8 \frac{\mathrm{rad}}{\mathrm{s}} .
$$

Therefore, the elastic system between the active and intermediate masses is designed as a set of eight flat springs (Fig. 5, a), and the vibration isolators are formed by six coil cylindrical springs (Fig. 5, b).

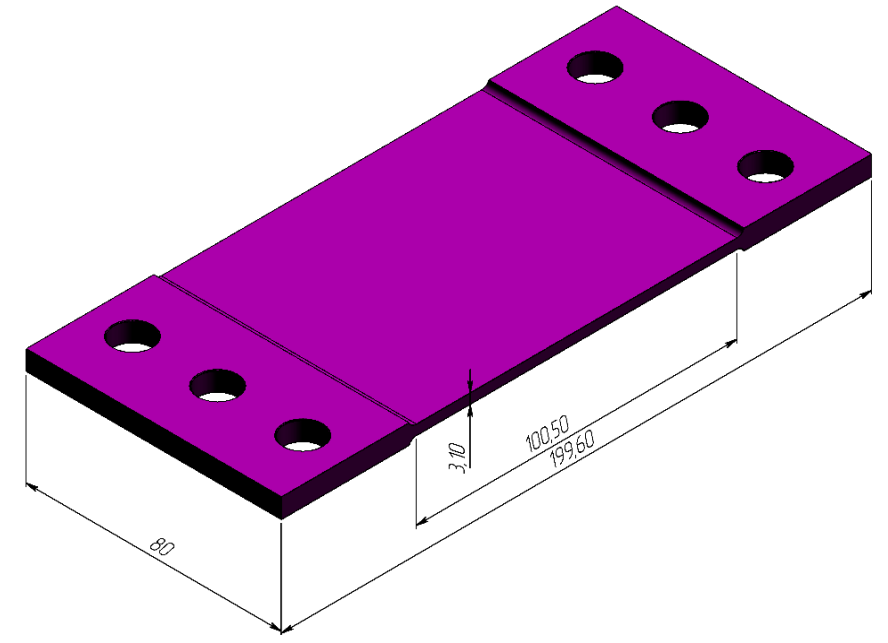

$a$
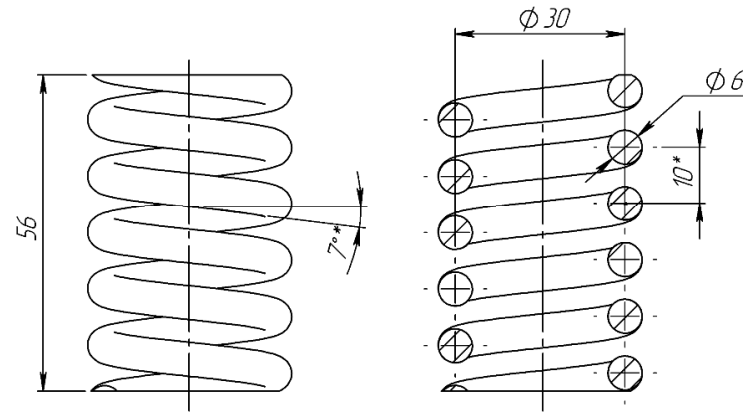

6

Fig. 5. The spring elements used in mechanical oscillatory system of the vibratory conveyer: $a$-flat spring between the active mass (tray) and intermediate mass (frame);

$b$-coil cylindrical spring between the frame and the supporting surface (foundation, base)

Рис. 5. Пружні елементи, які використовуються в механічній коливній системі вібротранспортера: a - плоска пружина між активною масою (лотком) і проміжною масою (корпусом);

$b$ - вита ичиліндрична пружина між корпусом і опорною поверхнею (фундаментом, основою)

One of the fundamental peculiarities of analysis, calculation and designing of oscillatory systems of vibratory conveyers, in which it is implemented the energy-efficient (high-performance) resonant operation mode based on the "zero-stiffness" phenomenon, consists in conventional neglecting the parameter of stiffness of the spring system between the intermediate and reactive masses assuming that $c_{2} \ll c_{1}$ and $c_{2} \rightarrow 0[6,7]$.

Constructing amplitude-frequency characteristics of the mechanical oscillatory system of the vibratory conveyer. In the material presented above, there have already been substantiated the basic inertial and stiffness parameters of the oscillatory system of the vibratory conveyer: $m_{a}=56.742 \mathrm{~kg}$, $m_{n}=36.055 \mathrm{~kg}, m_{p}=3.858 \mathrm{~kg}, c_{1}=2.313 \cdot 10^{6} \mathrm{~N} / \mathrm{m}, c_{i 3}=77000 \mathrm{~N} / \mathrm{m}, c_{2} \approx 0$. In order to construct the corresponding amplitude-frequency characteristics using the derived dependencies (10) and (11), it is necessary to prescribe the parameters of the system's excitation.

In the drive of the vibratory conveyer, there are used four unified electromagnetic vibration exciters with the nominal tractive force $F_{0}=120 \mathrm{~N}$. Thus, in further analysis, there will be considered the amplitude value of the total excitation force $P=480 \mathrm{~N}$.

Substituting the presented above parameters of the mechanical oscillatory system of the vibratory conveyer into the equations (10) and (11), and adopting the resonant correction $z=0.97$, there were obtained the amplitude-frequency characteristics (Fig. 6) and time dependencies of displacements of the oscillating masses (Fig. 7) in the steady-state operation mode of the vibratory conveyer. 

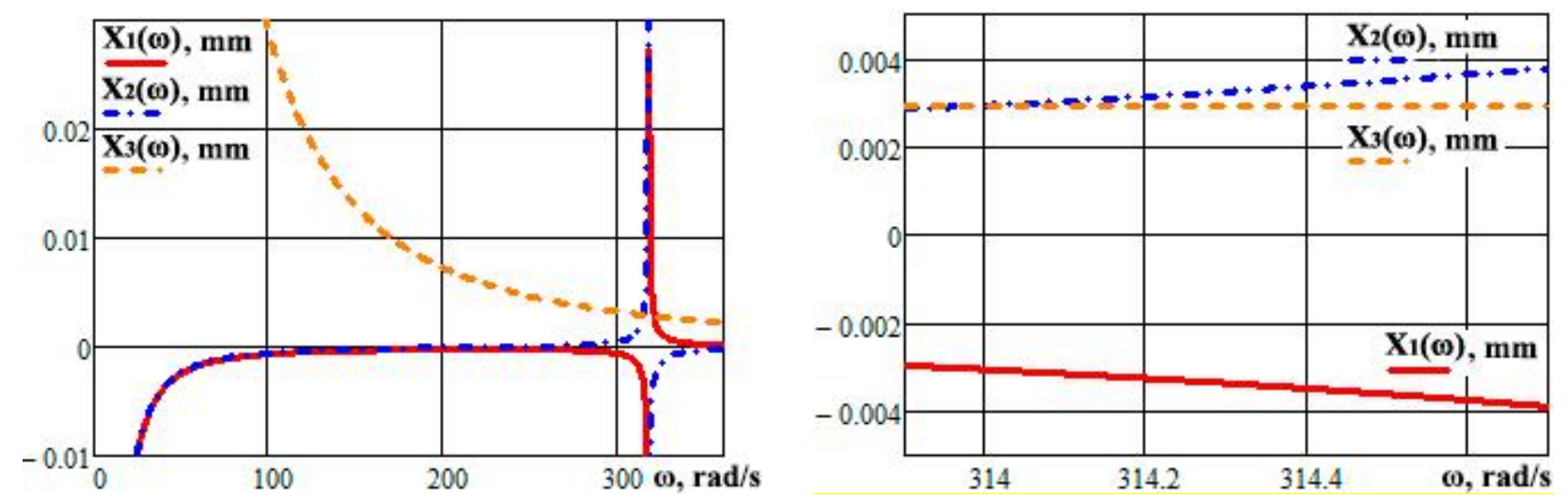

Fig. 6. Amplitude-frequency characteristics of the three-mass oscillatory system of the vibratory conveyer:

1 -active mass; 2 - intermediate mass; 3 - reactive mass

Рис. 6. Амплітудно-частотні характеристики тримасової коливальної системи вібротранспортера: 1 - активної маси; 2 - проміжної маси; 3 - реактивної маси

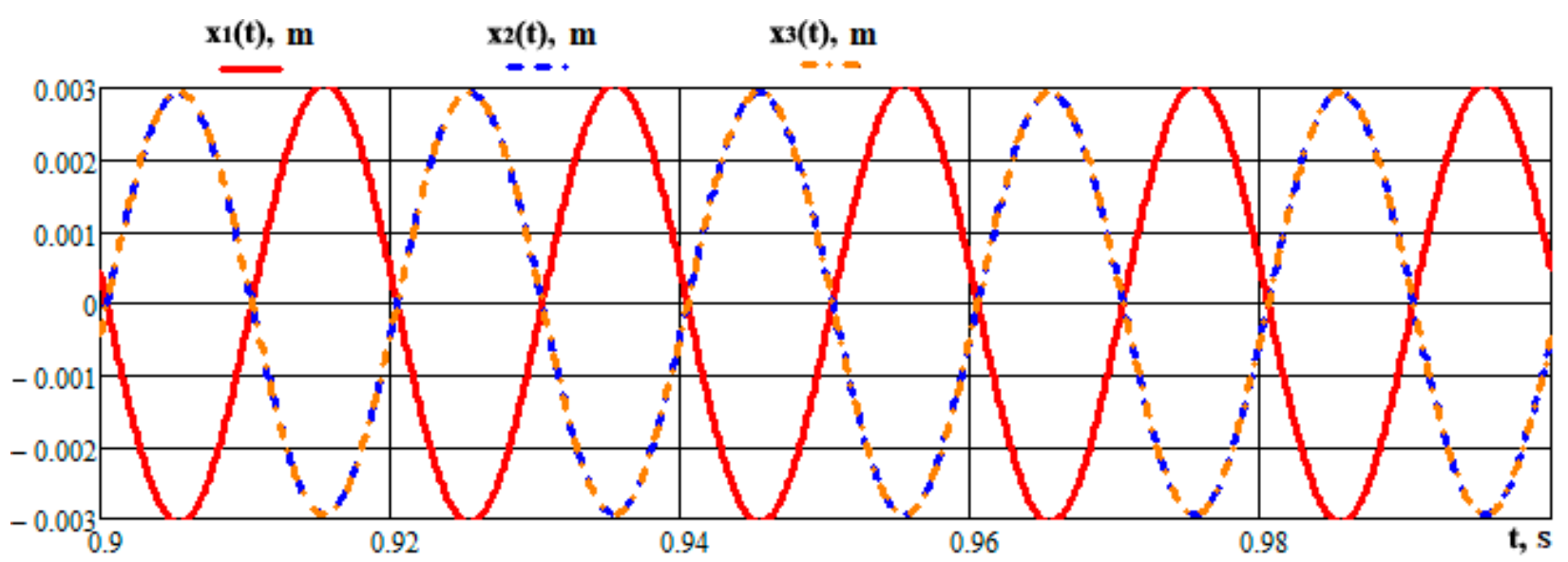

Fig. 7. Time dependencies of displacements of the oscillating masses in the steady-state operation mode of the vibratory conveyer constructed on the basis of formulas (10) and (11) in MathCAD software: 1 -active mass; 2 - intermediate mass; 3 - reactive mass

Рис. 7. Часові залежності переміщень коливальних мас в усталеному режсмі роботи вібротранспортера, побудовані на основі формул (10) і (11) в програмному продукті MathCAD:

1 -активна маса; 2 - проміжна маса; 3 -реактивна маса

Analysing the obtained amplitude-frequency characteristics and time dependencies of displacements of the oscillating masses, one can state that at the forced frequency of $50 \mathrm{~Hz}(314 \mathrm{rad} / \mathrm{s})$ the nominal amplitude of oscillations of the working bodies of the vibratory conveyer operating in steady-state mode reach $0.003 \mathrm{~m}(3 \mathrm{~mm})$. Herewith, the reactive mass and the intermediate one oscillate at the same phase, whereas the active mass oscillates at the opposite phase. This fact proves the implementation of the "zero stiffness" phenomenon and the highly efficient (high-performance) operation mode [6, 7].

Numerical (computational) solving the differential equations of the system's motion in MathCAD software. The input parameters for further analysis of motion of the oscillatory system of the vibratory conveyer are following:

- inertial parameters of the investigated oscillatory system: $m_{a}=56.742 \mathrm{~kg}, m_{n}=36.055 \mathrm{~kg}$ (obtained on the basis of solid-state designing of the conveyer), $m_{p}=3.858 \mathrm{~kg}$ (determined by the expression (12)); 
- stiffness parameters of the oscillatory system and vibration isolators: $c_{1}=2.313 \cdot 10^{6} \mathrm{~N} / \mathrm{m}$ (determined by formula (14)), $c_{i 3}=77000 \mathrm{~N} / \mathrm{m}$ (determined by expression (19)), $c_{2} \approx 0$ (is substantiated by the "zero stiffness" phenomenon $[6,7])$;

- excitation parameters: $P=480 \mathrm{~N}, \omega=314 \mathrm{rad} / \mathrm{s}(50 \mathrm{~Hz}$ ) (defined by the parameters of the electromagnetic vibration exciter and by the scheme of powering the electromagnets);

- initial conditions: the initial lengths and deviations of all spring elements are equal to the ones in static (steady) state; the initial positions and speeds of all oscillating masses equal zero $\left(x_{1}(0)=0 \mathrm{~m}\right.$, $\left.x_{2}(0)=0 \mathrm{~m}, x_{3}(0)=0 \mathrm{~m}, \dot{x}_{1}(0)=0 \mathrm{~m}, \dot{x}_{2}(0)=0 \mathrm{~m}, \dot{x}_{3}(0)=0 \mathrm{~m}\right)$.

The results of simulation of the system's motion during the time periods of $0.5 \mathrm{~s}$ and $1.6 \mathrm{~s}$ are presented in Fig. 8, a, b, respectively.

Based on the results of the carried out simulation of motion of the oscillating masses of the mechanical system of the vibratory conveyer (Fig. 8), one can state that the maximal amplitude of oscillations of the reactive mass equals $X_{3}=0.003 \mathrm{~m}$ and corresponds to the results of theoretical investigations (Fig. 7).

Analysing the obtained graphical dependencies of the amplitudes of oscillating masses of the vibratory conveyer in the range of frequencies close to resonant one (Fig. 8), one can observe almost equal amplitudes of oscillations of the intermediate mass (conveyer's frame) and the reactive mass (electromagnets' armatures). This proves their in-phase motion and implementation of the "zero stiffness" phenomenon [6,7]. The amplitude of oscillations of the active mass (tray) is at the opposite phase with respect to the ones of the other two bodies, whereas the magnitude of the amplitudes of all bodies are almost equal (Fig. 8). This is proven by the results of modelling the motion of the oscillating masses using the analytical dependencies (10) and (11) (Figs. 6 and 7), as well as by the results of numerical solving of the system (7) of differential equations of motion of the oscillating masses in MathCAD software (Fig. 8). The system needs almost after $1 \mathrm{~s}$ to provide the in-phase motion of the intermediate and reactive masses at the opposite phase to the motion of the active mass (Fig. 8, $b$ ).

Analysing the influence of excitation parameters on the system's motion. In this section of the paper, there will be carried out the analysis of motion of the oscillating masses under the conditions of different amplitudes of the excitation force and different forced frequencies. This analysis will allow to substantiate the adequacy of the proposed mathematical model for describing the dynamics of the mechanical oscillatory system of the vibratory conveyer.

In particular, the change of the amplitude of the excitation force should cause the proportional change of the amplitudes of displacements of the oscillating masses. The sufficient change of the excitation frequency "pushes" the system out of the resonant operation mode, and should cause corresponding reduction of the amplitudes of oscillations of the intermediate and active masses.

In order to carry out further simulation, let us consider the following cases of operation of the vibratory conveyer (see Table below).

Table

The investigated cases of operation of the vibratory conveyer

\begin{tabular}{|l|l|}
\hline a) $P=240 \mathrm{~N}, \omega=314 \mathrm{rad} / \mathrm{s}(\approx 50 \mathrm{~Hz})$ & б) $P=720 \mathrm{~N}, \omega=314 \mathrm{rad} / \mathrm{s}(\approx 50 \mathrm{~Hz})$ \\
\hline в) $P=480 \mathrm{~N}, \omega=157 \mathrm{rad} / \mathrm{s}(\approx 25 \mathrm{~Hz})$ & г) $P=480 \mathrm{~N}, \omega=628 \mathrm{rad} / \mathrm{s}(\approx 100 \mathrm{~Hz})$ \\
\hline
\end{tabular}

The results of simulation of motion of the mechanical oscillatory system of the vibratory conveyer under the conditions listed above are presented in Fig. 9. Analysing the obtained graphical dependencies, one can state that the reduction of the amplitude value of the excitation force by 2 (from $480 \mathrm{~N}$ to $240 \mathrm{~N}$ ) causes the proportional decrease of the amplitude of oscillations of the working masses almost by 2 (from 
$3 \mathrm{~mm}$ to $1.5 \mathrm{~mm}$ ) (Fig. 9 a). The increase of the excitation force by 1.5 (from $480 \mathrm{~N}$ to $720 \mathrm{~N}$ ) causes the proportional increase of the amplitudes of all the masses of the system almost by 1.5 also (from $3 \mathrm{~mm}$ to $4.5 \mathrm{~mm}$ ) (Fig. 9, b).
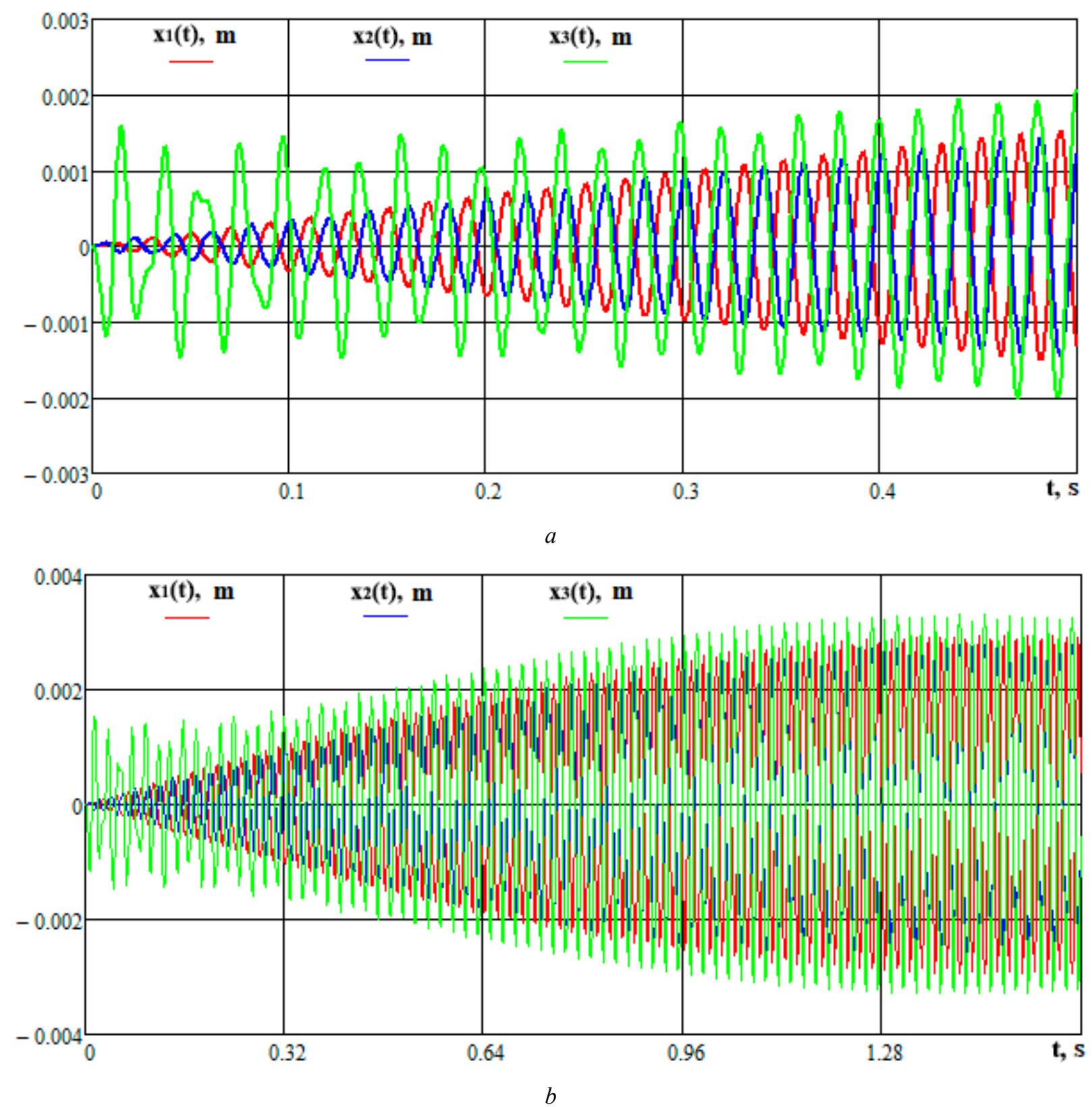

Fig. 8. Time dependencies of displacements of the oscillating masses constructed on the basis of the results of numerical solving of the system of differential equations (7) in MathCAD software:

1 -active mass; 2 - intermediate mass; 3 - reactive mass

Рис. 8. Часові залежності перемімень коливальних мас, побудовані за результатами чисельного розв' язування системи диференціальних рівнянь (7) у програмному продукті МathCAD:

1 -активна маса; 2 - проміжна маса; 3 -реактивна маса

The change of frequency of the excitation force by 2 (case c - from $50 \mathrm{~Hz}$ to $25 \mathrm{~Hz}$; case d - from $50 \mathrm{~Hz}$ to $100 \mathrm{~Hz}$ ) causes significant reduction of the amplitudes of oscillations of the intermediate and active masses (Fig. 9, $c, d$ ). This fact is absolutely normal (natural) phenomenon, because there takes place the system's "pushing" out of the resonant operation mode. 

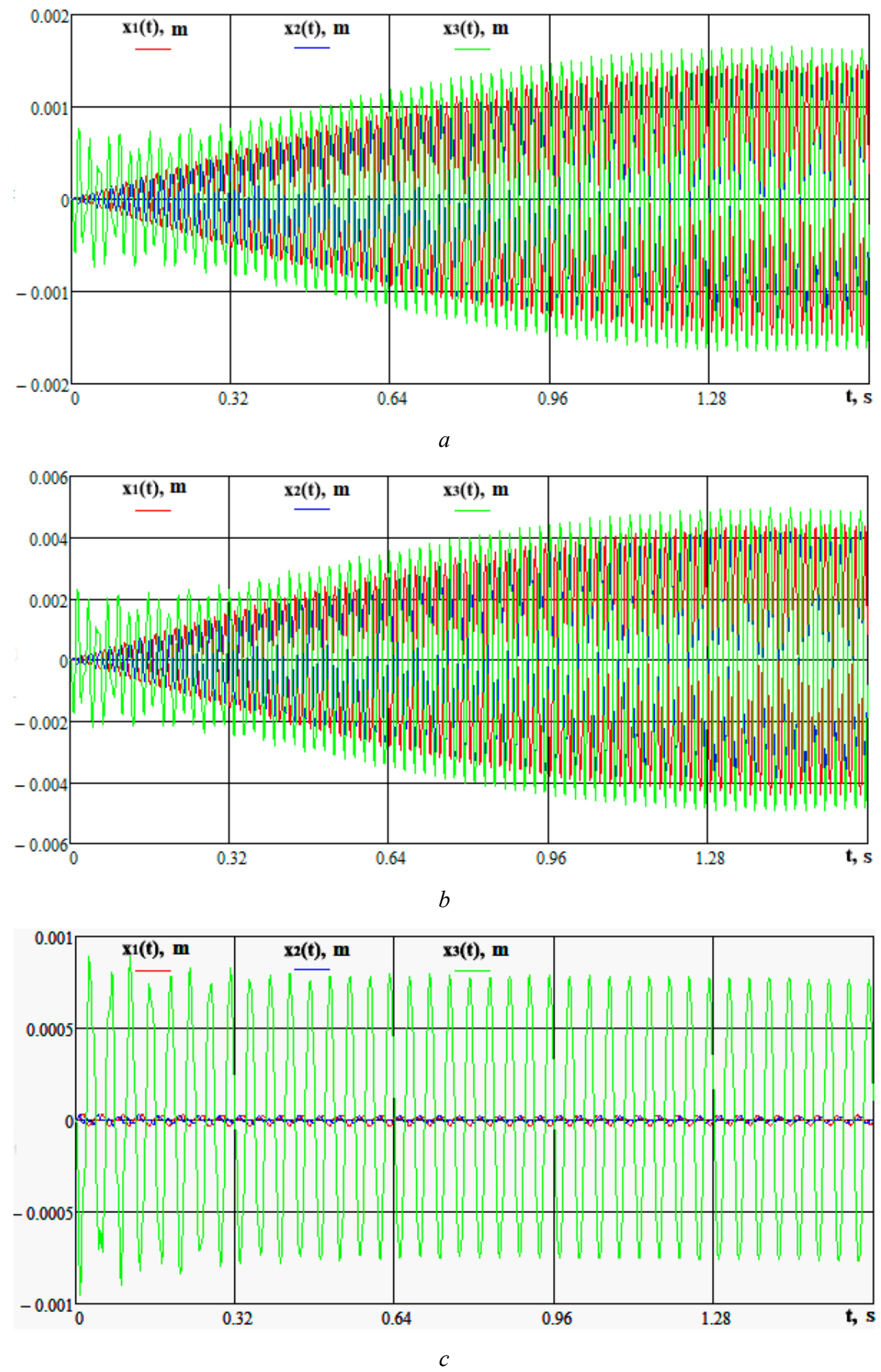

Fig. 9. Time dependencies of displacements of the oscillating masses under different excitation parameters constructed on the basis of the results of numerical solving of the system of differential equations (7) in MathCAD software: 1 -active mass; 2 -intermediate mass; 3 -reactive mass

Рис. 9. Часові залежності переміщень коливальних мас за різних параметрів збурення, побудовані за результатами чисельного розв'язування системи диференціальних рівнянь (7) у програмному продукті MathCAD: 1 - активна маса; 2 - проміжна маса; 3 - реактивна маса 


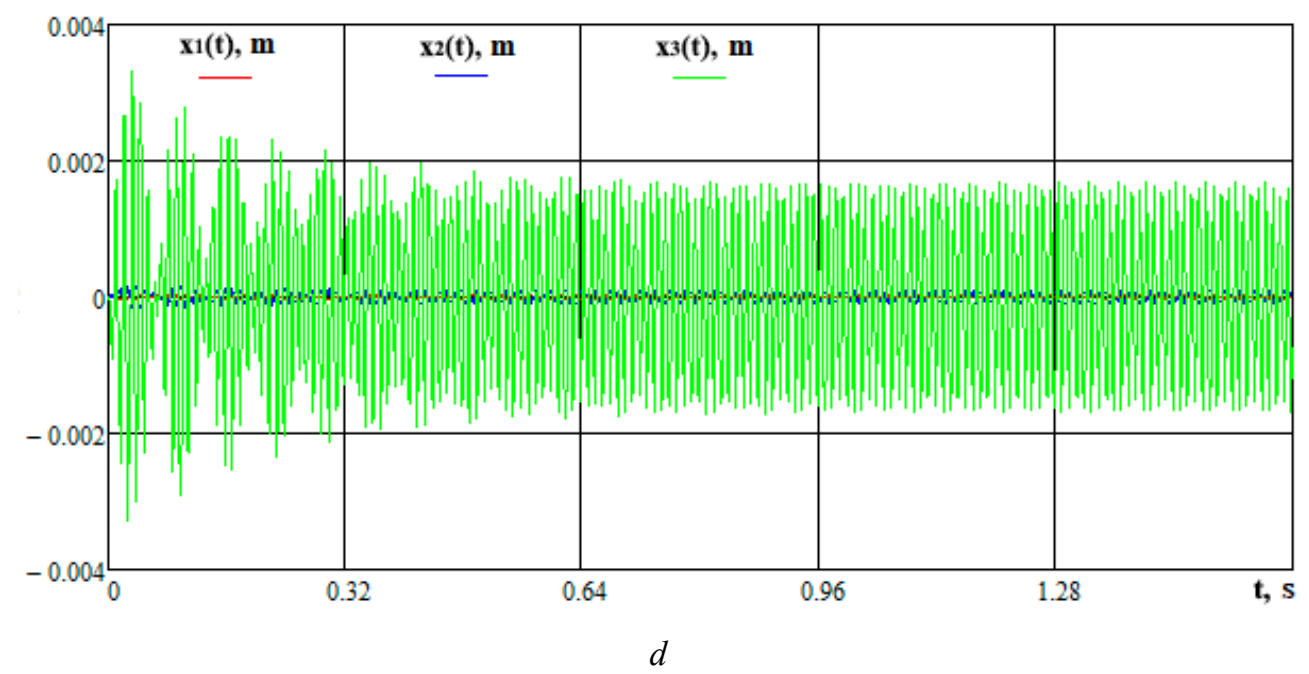

Fig. 9. (Продовження). Time dependencies of displacements of the oscillating masses under different excitation parameters constructed on the basis of the results of numerical solving of the system of differential equations (7) in MathCAD software: 1 -active mass; 2 -intermediate mass; 3 -reactive mass

Pис. 9. (Cоntinuation). Часові залежності переміщень коливальних мас за різних параметрів збурення, побудовані за результатами чисельного розв'язування системи диференціальних рівнянь (7) в програмному продукті МатһCAD: 1 - активна маса; 2 - проміжна маса; 3 - реактивна маса

Conclusions. In the paper, the structural and operational peculiarities of the three-mass vibratory conveyer with directed oscillations of the working bodies were considered. The fields of its possible implementation were overviewed. The structure of the conveyer's mechanical oscillatory system was analysed, and on the basis of the Lagrange equations of the second order, the mathematical model describing the system's motion under the action of sinusoidal excitation force applied between the intermediate and reactive masses was derived. Using the general methods of solving the systems of linear nonhomogeneous differential equations with constant coefficients, the expressions for determining the amplitudes of oscillations of all the mases in the steady-state operation mode were deduced.

The technique (algorithm) of determining inertial and stiffness parameters of mechanical oscillatory system of vibratory conveyer with directed oscillations of the working bodies was presented. In accordance with the given masses of the working element (tray) and frame of the conveyer, there were calculated the stiffness of the corresponding spring elements and vibration isolators, as well as the value of the reactive (disturbing) mass. Also, there were chosen the parameters of excitation.

Based on the derived expressions for amplitudes of oscillations of the working masses and taking into account the determined inertial, stiffness and excitation parameters of the oscillatory system of the vibratory conveyer, there were constructed the amplitude-frequency characteristics and the time dependencies of displacements of the oscillating masses in the steady-state operation mode.

Using the derived mathematical model of the three-mass mechanical oscillatory system of the vibratory conveyer and the determined inertial, stiffness and excitation parameters, there was simulated the motion of the oscillating masses. Based on the results of the simulation, there was drawn the conclusion about the agreement of the results of the theoretical investigations with the ones obtained after carrying out virtual experiment. The in-phase motion of the intermediate and reactive masses was substantiated. This allowed to draw a conclusion about implementation of the "zero stiffness" phenomenon in order to provide the highly efficient resonant operation mode of the vibratory conveyer.

In order to analyse the adequacy of the proposed mathematical model of the mechanical oscillatory system of the vibratory conveyer, there was investigated the influence of the amplitude and frequency of the excitation force on the motion characteristics of the oscillating masses. In particular, the cases of changing the forced frequency (decreasing and increasing by 2) and changing the amplitude (decreasing by 
2 and increasing by 1.5) were considered. There was substantiated that the change of the amplitude of the excitation force causes the proportional change of the amplitudes of the working masses, whereas the change of the forced frequency causes significant reduction of the amplitudes of oscillations of the intermediate and active mass.

1. J. P. Den Hartog, Mechanical Vibrations, New York: McGraw Hill, 1956.

2. H. Benaroya, M. Nagurka, and S. Han, Mechanical Vibration. Analysis, Uncertainties, and Control. Boca Raton: CRC Press, 2018.

3. Singiresu S. Rao, Mechanical Vibrations. Harlow, United Kingdom: Pearson, 2017.

4. Bangchun Wen, et al, Vibrating Machinery. Theory, Techniques and Applications. Beijing, China: Science Press, 2012.

5. V. O. Povidailo, Vibratsiini protsesy ta obladnannia [Vibratory processes and equipment]. Lviv, Ukraine: Vydavnytstvo Natsionalnoho universytetu "Lvivska politekhnika" Publ., 2004. [in Ukrainian].

6. O. S. Lanets, Vysokoefektyvni mizhrezonansni vibratsiini mashyny z elektromahnitnym pryvodom. Teoretychni osnovy ta praktyka stvorennia [High-performance inter-resonant vibratory machines with electromagnetic drive. Theoretical fundamentals and practice of development]. Lviv, Ukraine: Lviv Polytechnic Publishing House, 2008, 324 p. [in Ukrainian].

7. O. Lanets, Osnovy rozrakhunku ta konstruiuvannia vibratsiinykh mashyn [Fundamentals of Analysis and Design of Vibratory Machines]. Lviv, Ukraine: Lviv Polytechnic Publishing House, 2018. [in Ukrainian].

8. V. M. Gursky, Bahatokryterialnyi analiz i syntez neliniinykh rezonansnykh vibratsiinykh mashyn [MultiCriteria Analysis and Synthesis of the Nonlinear Resonant Vibratory Machines]. Lviv, Ukraine: Lviv Polytechnic Publishing House, 2017. [in Ukrainian].

9. V. Korendiy, et al, "Modelyuvannya roboty trymasovoho vibrotransportera $\mathrm{z}$ napryamlenymy kolyvannyamy robochoho orhanu" ["Modelling the operation of the three-mass vibratory conveyer with directed oscillations of the working element"], in Proc. 14-th International Symposium of Ukrainian Mechanical Engineers in Lviv, Lviv, Ukraine, 23-24 May 2019, pp. 136-138. [in Ukrainian].

10. M. R. Hatch, Vibration Simulation Using MATLAB and ANSYS. Boca Raton: CRC Press, 2001.

11. P. M. Kurowski, Vibration Analysis with SOLIDWORKS Simulation 2018. Mission, KS, USA: SDC Publications, 2018.

В. М. Корендій, О. Ю. Качур, Ю. Я. Новіцький, В. А. Мазурик, В. А. Середа Національний університет "Львівська політехніка"

\section{ОБГРУНТУВАННЯ ПАРАМЕТРІВ ТА МОДЕЛЮВАННЯ РОБОТИ ТРИМАСНОГО ВІБРОТРАНСПОРТЕРА 3 НАПРЯМЛЕНИМИ КОЛИВАННЯМИ РОБОЧОГО ОРГАНУ}

(C) Корендій В. М., Качур О. Ю., Новіиький Ю. Я., Мазурик В. А., Середа В. А., 2019

Проаналізовано конструктивні і функціональні особливості тримасового вібротранспортера 3 напрямленими коливаннями та розглянуто можливі сфери його використання.

Проаналізовано основні навантаження на елементи механічної коливальної системи вібротранспортера та на основі диференціальних рівнянь Лагранжа II роду розроблено іï математичну модель, яка описує рух системи за прикладання синусоїдальної збурюючої сили між проміжною та реактивною масами системи. Використовуючи загальні методи розв'язування систем лінійних неоднорідних диференціальних рівнянь зі сталими коефіцієнтами, отримано вирази для знаходження амплітуд коливань усіх мас системи в усталених режимах роботи.

Наведено алгоритм розрахунку інерційно-жорсткісних параметрів механічної коливної системи вібротранспортера 3 напрямленими коливаннями. Відповідно до заданих мас робочого органу і рами транспортера визначено жорсткості відповідних пружних елементів і віброізоляторів, величину реактивної (збурювальної) маси та підібрано характеристики електромагнітного віброзбуджувача.

На основі виведених залежностей амплітуд коливань робочих мас в усталених режимах роботи та 3 урахуванням розрахованих інерційних, жорсткісних і силових параметрів коливної системи вібротранспортера побудовано відповідні амплітудно-частотні характеристики та часові залежності переміщень коливальних мас. Встановлено, що номінальна амплітуда коливань робочих тіл вібротранспортера в усталеному режимі роботи досягає 3 мм. 
За розрахованими параметрами коливної системи та параметрами збурення за допомогою побудованої математичної моделі тримасної коливної системи вібротранспортера було змодельовано іiі рух. За результатами імітаційного моделювання зроблено висновки про збіжність результатів аналітичних досліджень та віртуального експерименту. Обгрунтовано наявність синфазного руху проміжної і реактивної мас, зумовленого реалізацією ефекту “нульової жорсткості» з метою забезпечення високоефективного резонансного режиму роботи.

3 метою оцінювання адекватності запропонованої математичної моделі механічної системи вібротранспортера проаналізовано вплив частоти та амплітуди збурювального зусилля на характеристики руху коливних мас. Зокрема, проаналізовано випадки збільшення і зменшення збурювальної частоти удвічі та збільшення амплітуди в 1,5 разу і їі зменшення вдвічі. Обгрунтовано, що зміна амплітуди збурювального зусилля зумовлює пропорційну зміну амплітуди відхилень робочих мас від їх положень рівноваги, тоді як зміна частоти збурення зумовлює суттєве зменшення амплітуди коливань проміжної та активної мас, оскільки має місце "зсув» системи від резонансного режиму роботи.

Ключові слова: вібротранспортер, механічна коливна система, віброзбуджувач, резонансний режим роботи, інерційні параметри, жорсткісні параметри, параметри збудження, частота, амплітуда.

1. J. P. Den Hartog, Mechanical Vibrations, New York: McGraw Hill, 1956.

2. H. Benaroya, M. Nagurka, and S. Han, Mechanical Vibration. Analysis, Uncertainties, and Control. Boca Raton: CRC Press, 2018.

3. Singiresu S. Rao, Mechanical Vibrations. Harlow, United Kingdom: Pearson, 2017.

4. Bangchun Wen, et al, Vibrating Machinery. Theory, Techniques and Applications. Beijing, China: Science Press, 2012.

5. Повідайло В. О. Вібраційні процеси та обладнання. - Львів: Видавництво Національного університету “Львівська політехніка”, 2004. - 248 с.

6. Ланець О. С. Високоефективні міжрезонансні вібраційні машини з електромагнітним приводом. Теоретичні основи та практика створення : монографія. - Львів: Видавництво Національного університету “Львівська політехніка", 2008. - 324 с.

7. Ланець О. С. Основи розрахунку та конструювання вібраційних машин. Книга 1. Теорія та практика створення вібраційних машин з гармонійним рухом робочого органа: навчальний посібник / О. С. Ланець. Львів: Видавництво Львівської політехніки, 2018. - 612 с.

8. Гурський В. М. Багатокритеріальний аналіз і синтез нелінійних резонансних вібраційних машин: монографія / В. М. Гурський. - Львів: Видавництво Львівської політехніки, 2017. - 308 с.

9. Корендій В. М., Качур О. Ю., Дмитерко П. Р., Новіцький Ю. Я. Моделювання роботи тримасового вібротранспортера 3 напрямленими коливаннями робочого органа // 14-й Міжнародний симпозіум українських інженерів-механіків у Львові : матеріали симпозіуму, Львів, 23-24 травня 2019 р. - Львів : Кінпатрі ЛТД. - С. $136-138$.

10. M. R. Hatch, Vibration Simulation Using MATLAB and ANSYS. Boca Raton: CRC Press, 2001.

11. P. M. Kurowski, Vibration Analysis with SOLIDWORKS Simulation 2018. Mission, KS, USA: SDC Publications, 2018. 